\title{
An evaluation of drinking-usage water quality in terms of environmental health: A case study of Siverek (Sanliurfa), Turkey
}

\section{İçme kullanma suyu kalitesinin çevre sağlığı açısından değerlendirilmesi: Siverek (Şanlıurfa) örneği}

\author{
İbrahim BAYHAN ${ }^{1}$, Mehmet İrfan YEŞiLNACAR², Ayşegül DEMIR YETiş³ ${ }^{2}$ Engin TUTKUN ${ }^{4}$
}

\section{ABSTRACT}

Objective: Şanlıurfa city center and its districts were exposed to demographic high population movements with starting of the Southeastern Anatolia Project (GAP). Moreover, with the influence of refugees from Syria, it faced population pressure over the projected future population projections. One of the most significant effects of this population pressure from the perspective of infrastructure and environment has been the inability to successfully provide a healthy water supply system. In this study, it is aimed to demonstrate the effects of environmental pressure and changes in drinking-usage water quality. Siverek District was chosen as the largest district (4314 km² area; 2018 population total 258.265 people; center 146.131 people) in terms of representing the thirteen districts in the province.

Methods: The drinking-usage water system (water resources, reservoirs, and water networks) of the district was examined. Between January 2018 - September 2018, water samples were taken from nine sampling points seasonally under the "Water Sample Acceptance Criteria" published by the General Directorate of Public Health in 2018. $500 \mathrm{~mL}$ sterile sodium thiosulfate bottles were used for

\section{ÖZET}

Amaç: Şanlıurfa il merkezi ve ilçeleri, Güneydoğu Anadolu Projesi (GAP)'nin faaliyete geçmesiyle demografik açıdan yüksek nüfus hareketlerine maruz kalmıștır. Ayrıca Suriye'den gelen sığınmacıların da etkisiyle önceden tahmin edilen gelecek nüfus projeksiyonlarının üzerinde bir nüfus baskısı yașamıștır. Bu nüfus baskısının en önemli etkilerinden biri de çevre ve alt yapı açısından sağlıklı su yönetiminin başarılı bir șekilde icra edilememesidir. Bu çalıșmada, söz konusu çevresel baskıya ait etkilerin ve içme - kullanma suyu kalitesindeki değișimlerin ortaya çıkarılması amaçlanmıștır. İldeki mevcut on üç ilçeyi temsil etmesi bakımından en büyük ilçe olan Siverek ilçesi $(4.314$ km² yüz ölçümü, 2018 yılı nüfusu 258.265 kiși toplam, 146.131 kiși merkez) seçilmiștir.

Yöntem: İlçenin içme-kullanma suyu sistemi (su kaynakları, depoları ve su șebekesi) incelenmiștir. Ocak 2018 - Eylül 2018 tarihleri arasında, Halk Sağlığı Genel Müdürlüğü’nce 2018 yılında yayımlanan "Su Numunesi Kabul Kriterlerine" uygun șekilde dokuz örnekleme noktasından mevsimsel olacak şekilde su örnekleri alınmıștır. Mikrobiyolojik örnekler için 500

'Provincial Health Directorate, Public Health Services Department, Environmental Health Unit, Şanlıurfa, Turkey

${ }^{2}$ Harran University, Faculty of Engineering, Department of Environmental Engineering, Şanlıurfa, Turkey

${ }^{3}$ Bittis Eren University, Health Services and Vocational School, Department of Medical Services and Techniques, Environmental Health Program, Bitlis, Turkey

${ }^{4}$ Bozok University, Faculty of Medicine, Department of Public Health, Yozgat, Turkey

\footnotetext{
İletişim / Corresponding Author : İbrahim BAYHAN

Selahaddin Eyyubi Mah. R. Tayyip Erdoğan Bulvarı 63600 Şanlıurfa - Türkiye

E-posta / E-mail : ibayhan71@gmail.com
}

DOI ID : 10.5505/TurkHijyen.2020.40225

Bayhan I, Yeșilnacar Mi, Demir Yetiș A, Tutkun E. An evaluation of drinking-usage water quality in terms of environmental health: A case study of Siverek (Sanliurfa), Turkey. Turk Hij Den Biyol Derg, 2020; 77(EK4: Su ve Sağlık): 107-120 
microbiological samples and $1.5 \mathrm{~L}$ polyethylene bottles were used for chemical anaylsis. Coliform bacteria, Escherichia coli ( $E$. coli) and enterococci analysis were carried out by the membrane filtration method. Temperature, electrical conductivity, $\mathrm{pH}$ and free chlorine were measured as in situ. Fluoride, ammonium, nitrite, nitrate, sulfate, chloride as spectrophotometric; trihalomethanes, calcium, magnesium, sodium, potassium and iron parameters were made with ICP-OES (Inductively Coupled Plasma - Optical Emission Spectrometry) using EPA (United States Environmental Protection Agency) 200.7 method.

Results: According to the results of the analysis, it has been determined that the physicochemical parameters, excluding free chlorine, are in the appropriate range according to the criteria for "Regulation on Waters for Humanitarian Consumption (ITASHY)". In terms of microbiological parameters, significant inappropriate values were determined especially in the summer and fall seasons. In the microbiological analysis, coliform bacteria were detected in 15 samples $(42 \%), E$. coli were detected in nine samples (25\%) and enterococci were detected in three samples $(0.8 \%)$.

Conclusion: With the ongoing activities of the GAP, Sanliurfa and its districts have received a significant level of immigration from surrounding districts. This situation has also resulted in increased migration from rural areas to urban centers. Furthermore, following the Syrian civil war, Sanliurfa province has received the greatest impact of refugees in Turkey. This, in turn, had a negative effect on the management of transport, infrastructure, health, and the environment.

Key Words: Drinking-usage water, physicochemical, microbiological, Siverek, Sanliurfa
$\mathrm{mL}$ streil sodyum tiyosülfatlı șișeler, fizikokimyasal su örnekleri için ise 1,5 L'lik polietilen șișeler kullanılmıștır. Mikrobiyolojik analizlerden koliform bakteri Escherichia coli ( $E$. coli) ve enterokok analizleri membran filtrasyon yöntemi ile yapılmıștır. Fizikokimyasal analizlerden sıcaklık, elektriksel iletkenlik, pH ve serbest klor yerinde ölçülmüștür. Florür, amonyum, nitrit, nitrat, sülfat ve klorür analizleri spektrofotometrik; trihalometanlar, kalsiyum, magnezyum, sodyum, potasyum ve demir parametreleri ise ICP-OES (Indüktif Eșleșmiș PlazmaOptik Emisyon Spektrometresi) ile EPA (ABD Çevre Koruma Ajansı) 200.7 yöntemi kullanılarak yapılmıștır.

Bulgular: Analiz sonuçlarına göre, serbest klor hariç fizikokimyasal parametreler yönünden "İnsani Tüketim Amaçlı Sular Hakkında Yönetmelik (ITASHY)” kriterlerine göre uygun olduğu tespit edilmiștir. Mikrobiyolojik parametreler açısından ise özellikle yaz ve güz mevsimlerinde uygun olmayan sonuçlar görülmüștür. 15 örnekte (\%42) koliform bakteri, dokuz örnekte $(\% 25)$ E. coli, üç örnekte $(\% 0,8)$ enterokok bulunmuștur.

Sonuç: GAP'ın faaliyete geçmesiyle birlikte Şanlıurfa ve ilçeleri önemli oranda göç almıștır. Bu durum kırsaldan merkeze göçü de arttırmıștır. Ayrıca, Suriye'de yașanan iç savaș sonrasında ülkemize gelen sığınmacılardan en fazla etkilenen il olmuștur. $\mathrm{Bu}$ nüfus baskısının çevre ve alt yapı açısından su yönetimi üzerinde de önemli derecede olumsuz etkileri görülmüștür.

Anahtar Kelimeler: İçme-kullanma suyu, fizikokimyasal, mikrobiyolojik, Siverek, Şanlıurfa

\section{INTRODUCTION}

Allowing for age-related variations, it can be said that the human body is on average $70 \%$ water. The processes of transporting nutrients from the diet to the cells of the body and expelling the waste products of metabolism all depend on water. The physiological activities of the body can not take place without water (1). Water is also needed for cleaning and other domestic activities as well as for the preparation 
of food and other products for human consumption along with their presentation and marketing to the customer. The water needed for all these purposes is known as drinking-usage water, which must have the key feature of not presenting a risk to human health, whether physical, chemical or microbiological (2).

Throughout history, humans have employed a variety of different sources and systems to meet their need for drinking-usage water. Increasing population and urbanization increase water requirements with every passing day, while the exhaustion of water supplies and the physical, chemical and microbiological pollution of water have brought about a variety of human health problems. Therefore, water sources should be protected, water supply increased with appropriate techniques and closed water systems must be brought up to the necessary consumer standards (1). Unfortunately, some settlements still do not have such systems and even today have waterrelated health problems seen throughout history. Naturally, there has been a legal provision to ensure a safe and healthy supply of water to the consumer. In Turkey, the responsibility for healthy drinking-usage water supply lies with the local administration (3).

As a result of the activities associated with the Ataturk Dam and the Sanliurfa Irrigation Tunnels as part of the Southeastern Anatolia Project (GAP), Sanliurfa has received a significant amount of immigration from the surrounding province and districts. At the same time, there has been an increase in migration from the countryside to the provincial and district urban centers more generally. Especially in recent years, the influx of refugees to Turkey following the civil war in Syria has impacted this province more than any other. The educational, health and other infrastructure projects developed in preparation for these refugees were based on demographic projections that were well below the actual numbers, resulting in serious population pressure. This, in turn, had a negative effect on the management of transport, infrastructure, health, and the environment. In order to examine the impact of these environmental and infrastructure pressures on water management, Siverek was selected from the 13 districts of the province, which is the largest in terms of both area and population.

The district of Siverek covers $4.314 \mathrm{~km}^{2}$ and is in the north of Sanliurfa province. According to data obtained from The Turkish Statistical Institute (TUIK) (2018), the district has a total population of 258.265, with 146.131 living in the administrative center, making it larger even than many provinces in Turkey. To the west is the district of Kahta in Adiyaman Province; running from the west to the north is the reservoir of the Ataturk Dam; to the north lies Adiyaman's Gerger district along with Diyarbakir's Cermik and Cüngüs districts; to the east is the city of Diyarbakir, the administrative center of its province; and in the southeast, it has a short border with Mardin province in the form of Viransehir and Hilvan districts (Figure 1). From a geological perspective, Siverek lies in a region composed of basalt from the extinct volcano of Karacadag (4).

First of all, the district's existing drinking-usage water supply, including sources, reservoirs, and water networks, was examined. Between January 2018 and September 2018, seasonal samples of water delivered to the consumer and their physical, chemical and microbiological quality standards were determined. The results of the analysis were evaluated within the framework of the Regulation Concerning Water Intended for Human Consumption (ITASHY)(2). Additionally, the results were assessed for impact on environmental health.

\section{MATERIALS AND METHODS}

This study, which was conducted to investigate the quality of drinking-usage water in Siverek district, it was carried out with the permission (Official Gazette Date: 03.10.2016 and Number: 352) obtained from the General Directorate of Water and 


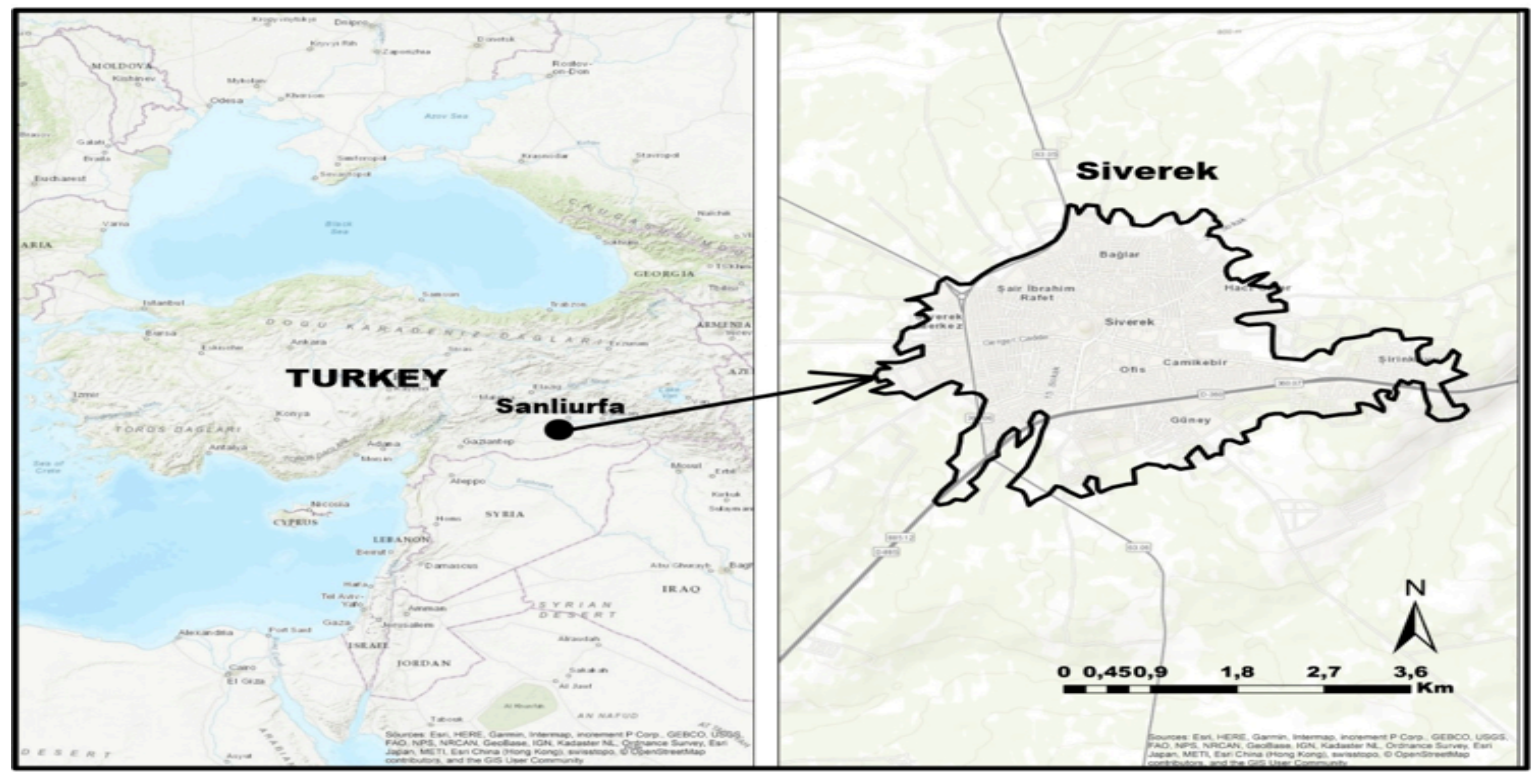

Figure 1. Study area location map.

Sewerage Administration of Sanliurfa Metropolitan Municipality (SUSKI). To begin with (initially), preliminary information was obtained on the extant water sources, reservoirs and systems from the Sanliurfa Water and Canalization Administration,
General Directorate and Sanliurfa Province Health Directorate. The exact water source coordinates were identified using a Magellan Triton GPS device (Figure 2).

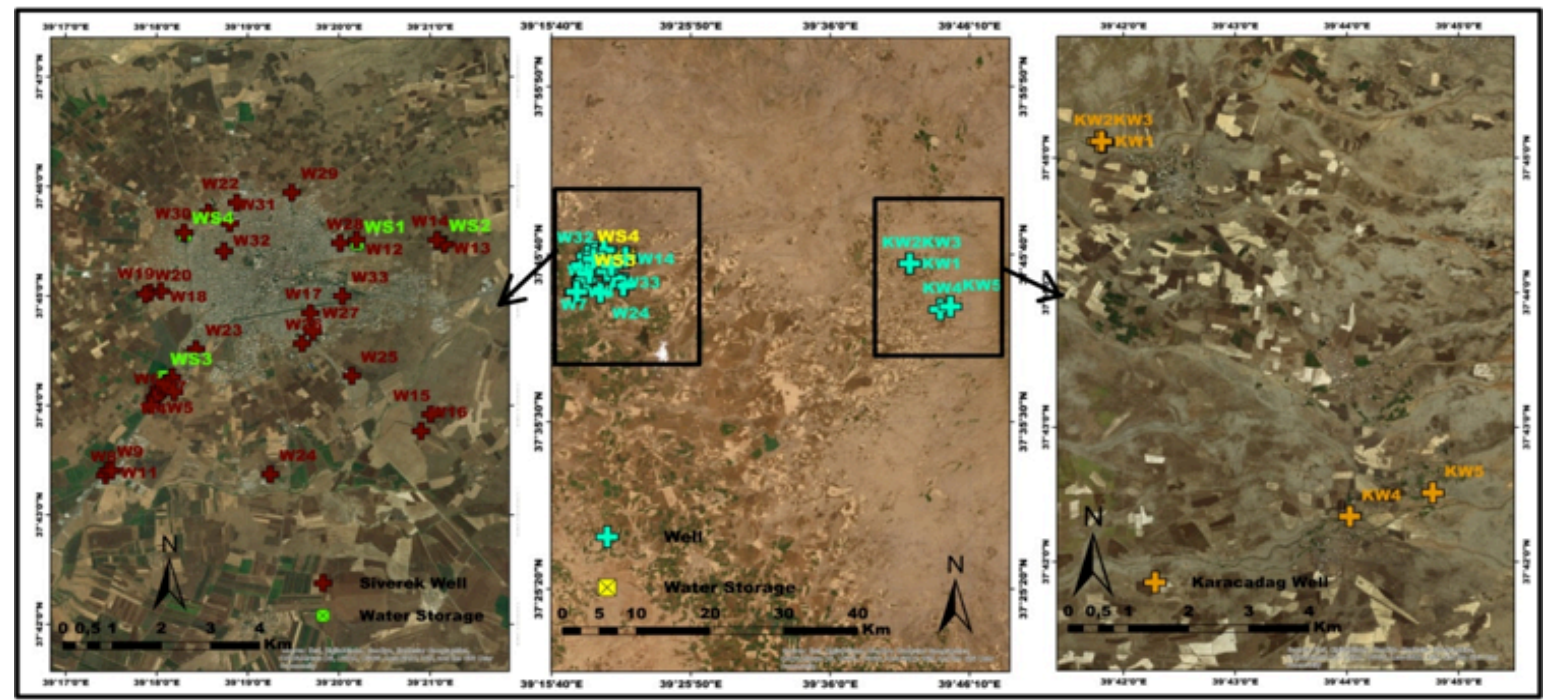

Figure 2. Wells and water reservoirs of study area 
The drinking-usage water samples were taken from survey points established by the District Health Directorate, where active water fountains and taps are supplied directly from the network (Figure 3). A total of nine sample points were used between January 2018 and September 2018 enabling a series of samples covering winter, spring, summer and fall that was representative of the entire water supply network.
The water samples were obtained and transported to the laboratory by the criteria laid out in the 2018 Criteria for Acceptable Water Specimens published by the Office of Public Health and Consumer Safety in the Public Health Directorate of the Health Ministry (5). Before the microbiological samples were taken, the mouth of the tap was cleaned with a cloth and any gauze or other filtration devices were removed from the tap. The water was allowed to flow until

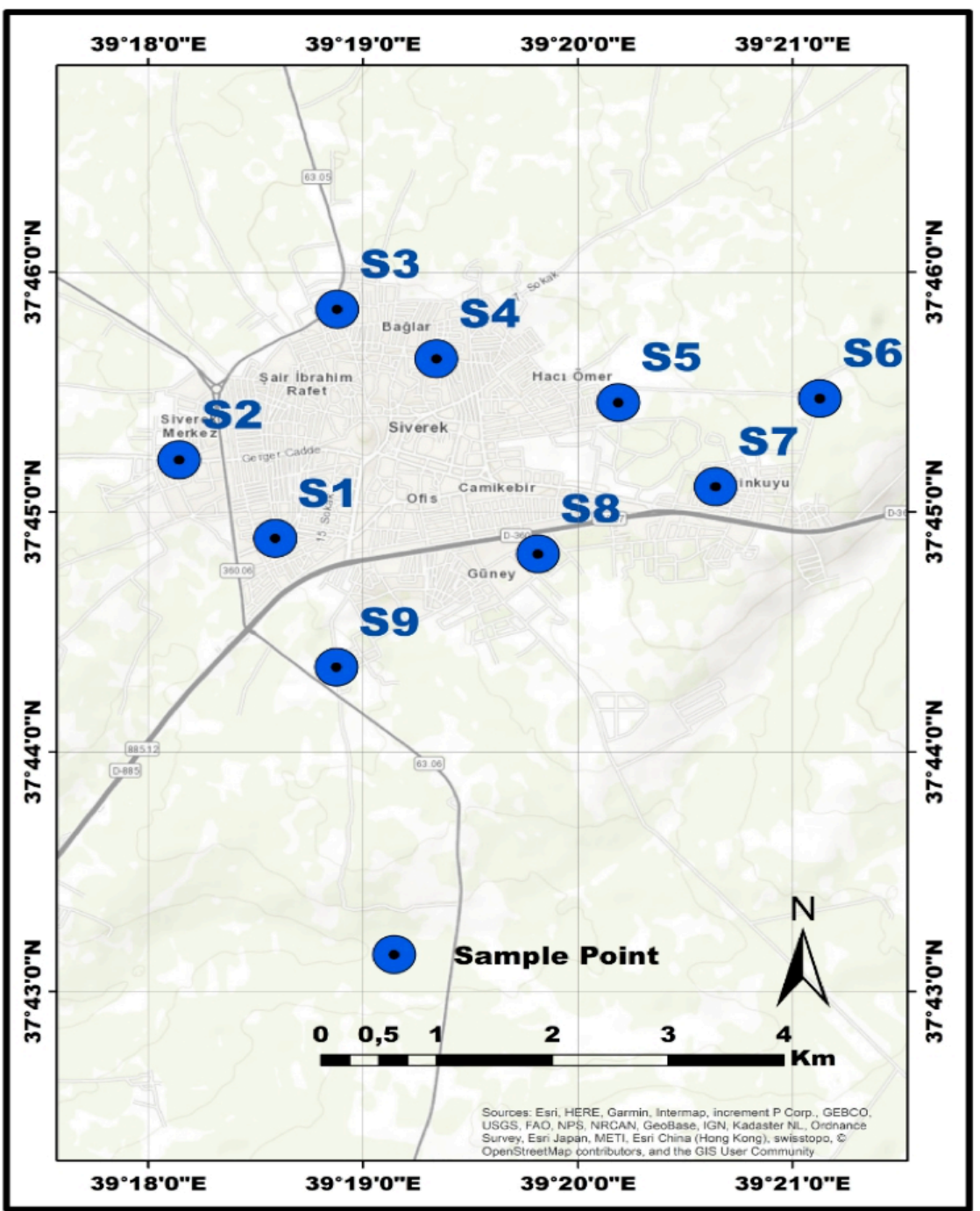

Figure 3. Location of sample points 
it reached a constant temperature, then the tap was closed and a flame passed over and around the mouth of the tap. When the sample container had been filled to the marker level, the lid was quickly replaced and the container labeled. The microbiological samples were obtained in sterile $500 \mathrm{~mL}$ sodium thiosulfate polypropylene bottles. The samples were taken into 1.5-L polyethylene bottles for physicochemical measurement. All collected samples were moved to SUSKI Drinking Water Purification Facility Laboratory in a cold chain $\left(+4{ }^{\circ} \mathrm{C}\right)$ with a delivery time of 4-6 hours.

Temperature, $\mathrm{pH}$, electrical conductivity and free chlorine were measured in situ during sampling. A Hach colorimeter was used to measure free chlorine levels. For free chlorine detection; two tubes of Hack colorimeter were filled with drinking water to be measured. One of the tubes was read into the device without adding any chemicals and the zero point was determined. The other free chlorine kit was added and shaken for 15 seconds to dissolve. Then, the amount of free chlorine was determined by putting it into the device. The $\mathrm{pH}$ and electrical conductivity values were measured in situ with the previously calibrated Hach HQ14D conductivity meter.

Measurements of microbiological analyses were carried out within the scope of HUBAK (Scientific Research Projects Committee of Harran University) Project in SUSKI Drinking Water Purification Facility Laboratory. Coliform bacteria, E. coli (TS EN ISO 9308-1), entorococci (TS EN ISO 78992) measurements were made using the membrane filtration method. The water samples were shaken slightly to make that homogeneous. $100 \mathrm{~mL}$ of the sample was filtered through membrane filters.

Measurements of physicochemical analyses were carried out within the scope of HUBAK Project in SUSKI Drinking Water Purification Facility Laboratory Analysis; fluoride, ammonium, nitrite, nitrate, sulfate and chloride as spectrophotometric; trihalomethanes, calcium, magnesium, sodium, potassium and iron parameters with ICP-OES (EPA 200.7 method) were made. The wavelength adjustment of the spectrophotometer was made based on the wavelength of the parameter and then the concentration values were measured. All water quality parameters, their units and the analytical methods are as given in Table 1.

The statistical analyses were conducted with SPSS 20 packet software. Central tendency (mode, median, arithmetical mean, maximum and minimum values) and distribution values (variation, standard deviation, coefficient of variation) were established. Normality and correlation analyses were carried out. About the data's maximum, minimum and arithmetical mean values, a comparison was made with the ITASHY limit values, If our variables are not normally distributed or if the number of sample units is below 30, the correlation between the variables is examined with the spearman correlation coefficient, which is a non-parametric method.

Maps of the study area were developed using ArcGIS ArcMap 10.1 Geographical Information System in topographical map sections mode. Distribution maps for the physicochemical parameters were created using Surfer Version 13.00 Golden Software, Inc.

\section{RESULTS}

Four water reservoirs, of which one is about to become a water supply center, and 38 borehole wells provide for the drinking-usage water needs of the district from groundwater sources. Unplanned additions were made to the existing water supply network as the city center grew. As the water from the reservoirs is fed to the network using gravity, these additions to the network result in an increased loss of head. For this reason, wells have been drilled in the neighborhoods furthest from the reservoirs, 
Table 1. Analytical method and unit of physicochemical and microbiological parameters in the study area

\begin{tabular}{|c|c|c|}
\hline Parameters & Analytical Method & Unit \\
\hline Temperature & Thermometer & ${ }^{\circ} \mathrm{C}$ \\
\hline Free chlorine & Colorimeter & ppm \\
\hline $\mathrm{pH}$ & TS EN ISO 10523 & \\
\hline Electrical conductivity & TS 9748 EN 27888 & $\mu \mathrm{S} / \mathrm{cm}$ \\
\hline Nitrite & Spectrophotometer & $\mathrm{mg} / \mathrm{L}$ \\
\hline Fluoride & Spectrophotometer & $\mathrm{mg} / \mathrm{L}$ \\
\hline Sulfate & Spectrophotometer & $\mathrm{mg} / \mathrm{L}$ \\
\hline Chloride & Spectrophotometer & $\mathrm{mg} / \mathrm{L}$ \\
\hline Nitrate & Spectrophotometer & $\mathrm{mg} / \mathrm{L}$ \\
\hline Ammonium & Spectrophotometer & $\mathrm{mg} / \mathrm{L}$ \\
\hline Iron & ICP-OES, EPA200.7 & $\mu g / L$ \\
\hline Calcium & ICP-OES, EPA200.7 & $\mathrm{mg} / \mathrm{L}$ \\
\hline Magnesium & ICP-OES, EPA200.7 & $\mathrm{mg} / \mathrm{L}$ \\
\hline Trihalomethanes & ICP-OES, EPA200.7 & $\mu \mathrm{g} / \mathrm{L}$ \\
\hline Sodium & ICP-OES, EPA200.7 & $\mathrm{mg} / \mathrm{L}$ \\
\hline Potassium & ICP-OES, EPA200.7 & $\mathrm{mg} / \mathrm{L}$ \\
\hline Coliform bacteria & TS EN ISO 9308-1 & $\mathrm{Cfu} / 100 \mathrm{~mL}$ \\
\hline E. coli & TS EN ISO 9308-1 & $\mathrm{Cfu} / 100 \mathrm{~mL}$ \\
\hline Enterococci & TS EN ISO 7899-2 & $\mathrm{Cfu} / 100 \mathrm{~mL}$ \\
\hline
\end{tabular}

and these wells connect directly to the network in order to supply the water needs of the residents. It was determined that there are 28 water wells within the district directly connected to the network. Automatic chlorinating devices were applied to the wells by SUSKI; however, as the chlorination is not carried out in a steady manner (regulation thresholds $0.3-0.5 \mathrm{ppm}$ ), there are occasional problems or high doses of chlorine administered, as identified by the free chlorine measurements while sampling (Table 2).
Thirty-six individual seasonal samples were taken from the nine survey points identified between January 2018 and September 2018. When evaluated in terms of seasonal changes, the minimum value for the temperature was measured as $17.5^{\circ} \mathrm{C}$ (winter-S1) and the maximum value was $28.6^{\circ} \mathrm{C}$ (summer-S4). The minimum value for $\mathrm{pH}$ was measured as 6.93 (winter-59) and the maximum value was measured as 7.4 (spring-S2). For electrical conductivity, the min value was measured as $279 \mu \mathrm{S} / \mathrm{cm}$ (spring-S6) and the max value was measured as $511 \mu \mathrm{S} / \mathrm{cm}$ (fall-S2). The 
Table 2. The detected minimum, maximum and mean values for all parameters, and ITASHY regulation limit values

\begin{tabular}{|c|c|c|c|c|}
\hline Parameter & $\begin{array}{l}\text { Detected } \\
\text { Minimum } \\
\text { Value }\end{array}$ & $\begin{array}{l}\text { Detected } \\
\text { Maximum } \\
\text { Value }\end{array}$ & $\begin{array}{c}\text { Detected } \\
\text { Average } \\
\text { Value }\end{array}$ & Regulation Limit Value \\
\hline Temperature $\left({ }^{\circ} \mathrm{C}\right)$ & 17.50 & 28.60 & 22.80 & - \\
\hline Free chlorine (ppm) & 0.00 & 5.80 & 1.00 & $0.3-0.5$ \\
\hline $\mathrm{pH}$ & 6.90 & 7.40 & 7.10 & $6.5-9.5$ \\
\hline Electrical conductivity $(\mu \mathrm{S} / \mathrm{cm})$ & 279.00 & 511.00 & 430.00 & 2500 \\
\hline Nitrite (mg/L) & 0.004 & 0.070 & 0.021 & 0.500 \\
\hline Fluoride (mg/L) & 0.01 & 0.96 & 0.15 & 1.50 \\
\hline Sulfate (mg/L) & 4.00 & 41.00 & 17.08 & 250 \\
\hline Chloride (mg/L) & 6.49 & 17.20 & 12.02 & 250 \\
\hline Nitrate (mg/L) & 1.20 & 25.60 & 8.70 & 50 \\
\hline Ammonium (mg/L) & 0.01 & 0.17 & 0.06 & 0.50 \\
\hline Iron $(\mu \mathrm{g} / \mathrm{L})$ & 0.010 & 0.220 & 0.054 & 200 \\
\hline Calcium (mg/L) & 25.46 & 66.35 & 40.88 & - \\
\hline Magnesium (mg/L) & 9.85 & 44.05 & 28.79 & - \\
\hline Trihalomethanes $(\mu \mathrm{g} / \mathrm{L})$ & 3.30 & 18.00 & 9.769 & 100 \\
\hline Sodium (mg/L) & 0.64 & 10.28 & 3.37 & 200 \\
\hline Potassium (mg/L) & 1.52 & 17.41 & 7.52 & - \\
\hline Coliform bacteria (Cfu/100 mL) & 0.00 & 250.00 & 54.31 & $0 / 100 \mathrm{ml}$ \\
\hline E. coli $(\mathrm{Cfu} / 100 \mathrm{~mL})$ & 0.00 & 250.00 & 23.25 & $0 / 100 \mathrm{ml}$ \\
\hline Enterococci (Cfu/100 mL) & 0.00 & 76.00 & 3.14 & $0 / 100 \mathrm{ml}$ \\
\hline
\end{tabular}

groundwater ammonium values ranged from 0.010 (winter) to $0.170 \mathrm{mg} / \mathrm{L}$ (spring-S1 and fall-S3); nitrite values from 0.004 (spring-S2) to $0.070 \mathrm{mg} / \mathrm{L}$ (winter-S1 and fall-S2); nitrate values from 1.20 (spring-S8) to $25.60 \mathrm{mg} / \mathrm{L}$ (winter-S1 and S5). Fluoride values ranged from 0.001 to $0.960 \mathrm{mg} / \mathrm{L}$ (winter-S5); sulfate values from 4.00 (spring-S8) to $41 \mathrm{mg} / \mathrm{L}$ (fall-S3); chloride values from 6.49 (fall-S4) to $17.20 \mathrm{mg} / \mathrm{L}$ (spring-S4). Calcium values ranged from 25.46 (winter-S2) to $66.35 \mathrm{mg} / \mathrm{L}$ (fall-S2); magnesium values from 9.85 (summer-S7) to $44.05 \mathrm{mg} / \mathrm{L}$ (spring-S7); sodium values from 0.64 (summer-S8) to $10.28 \mathrm{mg} / \mathrm{L}$ (winter-S2) and potassium values from 1.524 (fall-S1) to $17.41 \mathrm{mg} / \mathrm{L}$ (winter-S2). Iron and trihalomethanes values ranged from 0.010 to $0.22 \mu \mathrm{g} / \mathrm{L}$ (spring-S5) and from 3.3 (winter-S1) to $18.02 \mu \mathrm{g} / \mathrm{L}$ (spring-S1), respectively. According to the results of the parameter, excluding free chlorine, the samples were found to meet the standards of ITASHY (Table 2). Spatial distribution maps for the physicochemical parameters are shown in Figure. 4. 


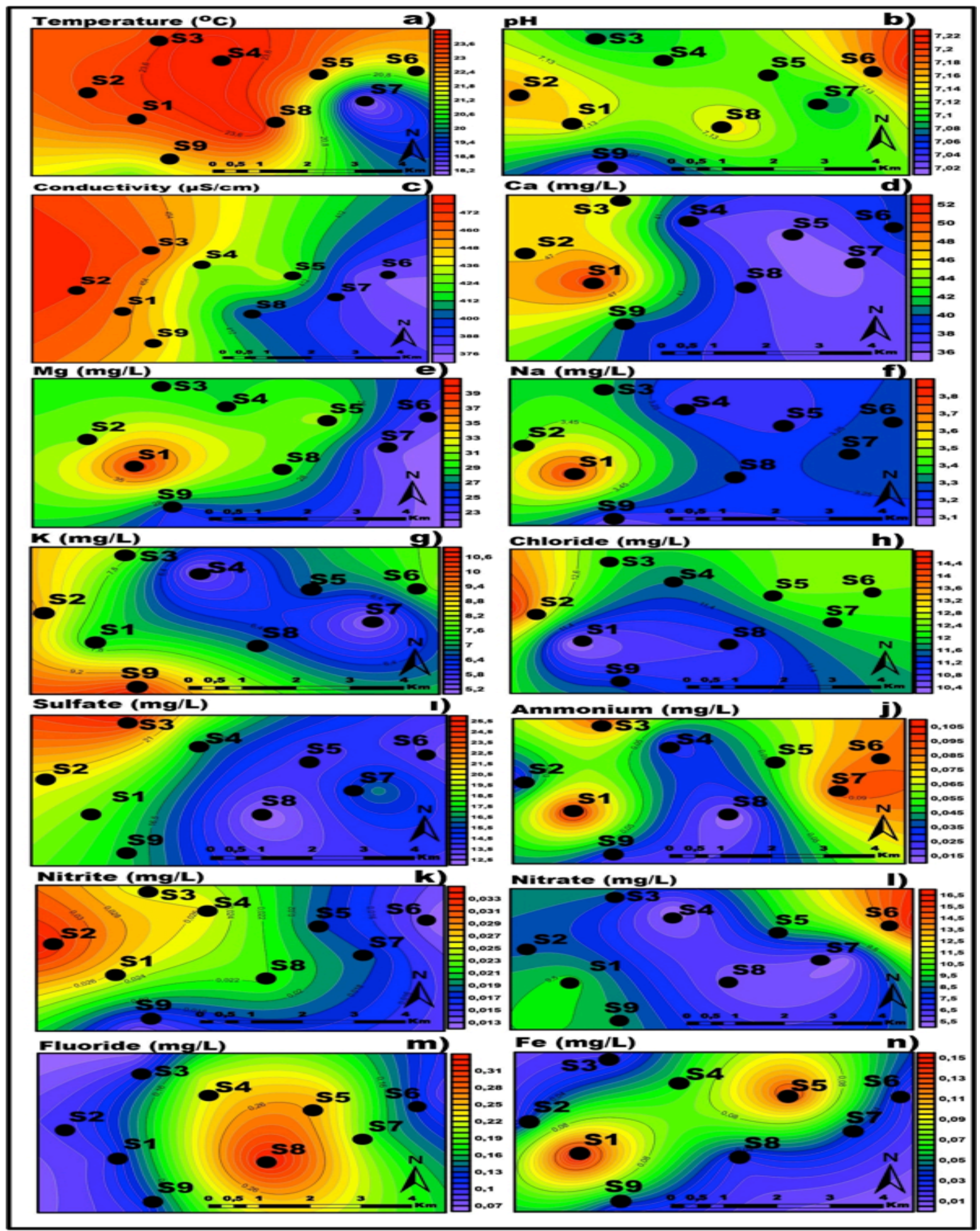

Figure 4. Spatial distribution maps for physicochemical parameters (a:temperature, b: pH, c:conductivity, d:Ca, e:Mg, f:Na, g:K, h:chloride, i:sulfate, j:ammonium, k:nitrite, l:nitrate, m:fluoride, n:Fe) 
In the microbiological analysis, 15 examples of coliform bacteria (42\%), nine examples of $E$. coli $(25 \%)$, and three examples of enterococci $(0.8 \%)$ were identified. The sample points exhibiting high microbiological unacceptability were also found to be those with a free chlorine level of zero (Figure 5). The other characteristic of these specific sample points is that they were within areas where wells were connected directly to the network without passing first into a depot or reservoir. It is thought that this situation may have arisen due to leaks into the well from the drainage/sewage system.

In order to determine the correlation between free chlorine and microbiological parameters, the Spearman's rho Correlation Test, a non-parametric test, was carried out. The correlation analyses found a medium level negative correlation between free chlorine and coliform bacteria $(r=-0,608)$; and a lowlevel negative correlation between free chlorine and E. coli $(r=-0.453)$ (Table 3). As $p=0.000$, this was a significant result from a statistical point of view.
Winter Period
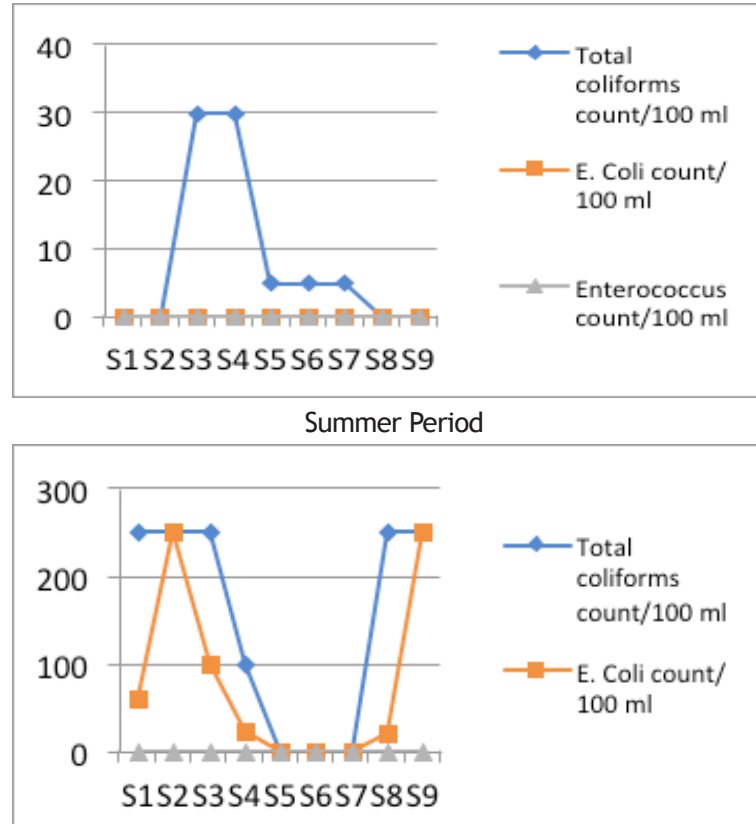

Figure 5. Seasonal distribution of microbiological parameters
Spring Period

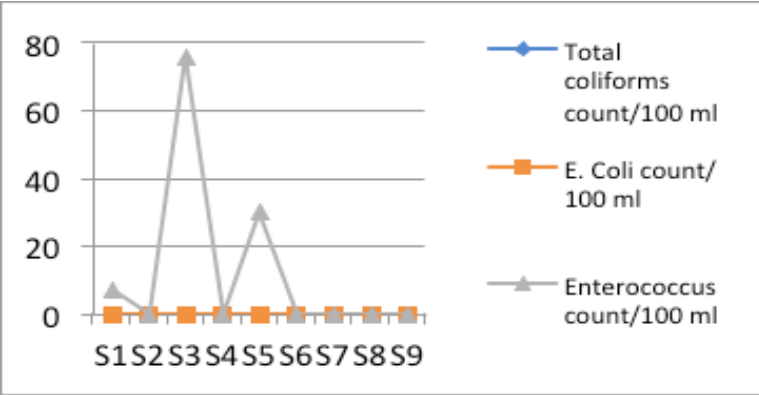

\section{Fall Period}

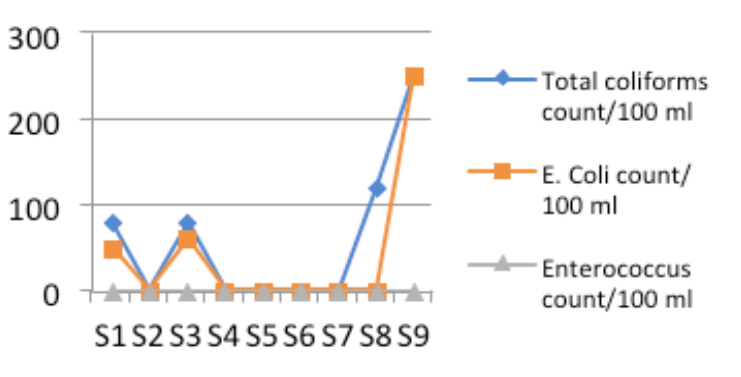

Table 3. Correlation of free chlorine with microbiological parameters

\begin{tabular}{|l|l|c|c|c|}
\hline \multicolumn{2}{|c|}{ Spearman's rho } & Coliform bacteria & E. coli & Enterococci \\
\hline \multirow{3}{*}{ Free_chlorine } & $\begin{array}{l}\text { Correlation } \\
\text { Coefficient }\end{array}$ & $-0.608^{* *}$ & $-0.453^{* *}$ & 0.141 \\
\cline { 2 - 5 } & Sig. (2-tailed) & 0.000 & 0.005 & 0.412 \\
\cline { 2 - 5 } & $\mathrm{N}$ & 36 & 36 & 36 \\
\hline
\end{tabular}

${ }^{* *}$ : Correlation is significant at the 0.01 level (2-tailed). 


\section{DISCUSSION}

Physicochemical and microbiological parameters measured in drinking water of Siverek district were evaluated in terms of environmental health, their suitability in terms of public health and potableness was discussed. In this context, although the measured temperature is not affected by seasonal changes, it is mostly lower in the winter season than the other periods. Temperature EC (electrical conductivity) value at $20{ }^{\circ} \mathrm{C}$ is the maximum permissible value of $650 \mu \mathrm{S} / \mathrm{cm}$ and $2500 \mu \mathrm{S} / \mathrm{cm}$, respectively. According to the results, the low measured EC value in this study showed that low salt content. In general, low concentrations were measured in all seasons as presented in a similar study (5). The $\mathrm{pH}$ of water provides vital information on many types of geochemical equilibrium or solubility calculations (6). In the study area, the measured $\mathrm{pH}$ value of samples was not exceeded permissible values and it appears to be neutral. Although the iron values in the groundwater of Siverek district were higher in the other periods compared to the winter period, the limit values were not exceeded. However, in a study in Harran plain near the study area, iron values were exceeded the permitted limit values (7). Although the fluoride values are higher than the other periods, the winter values did not exceed the limit values. Studies indicate that soluble fluoride in drinking water is the highest contributor to daily fluoride intake, and that drinking water is thus the most significant source of human fluoride ingestion (8). Although nitrogen (nitrite, nitrate and ammonium) is important for the sustainability of agriculture, it is a significant contaminant of groundwater (9). The measured nitrite and nitrate values are higher than the other periods in the winter period and have not exceeded the limit values. In another study conducted in the same region, incompatibility was detected in terms of measured high nitrate values (10). As a result of the increase in agricultural irrigations and the use of nitrated fertilizers with the get started of GAP, it has been observed that the groundwater in the region has contamination in terms of other physicochemical parameters, especially nitrate. While chloride was high in the spring period, sulfate was measured at high values in the fall period. However, it does not exceed the limit values again. In most natural waters, bicarbonate is the dominant anion, while bicarbonate sulfate and chloride were found in low amounts (5).

The waters used for drinking-usage should have a feature that does not cause disease in humans in terms of physical, chemical and microbiological quality parameters (2). It has been determined that the measurement results of the physicochemical parameters (excluding free chlorine) of the samples taken from the study area are within the limit value specified in ITASHY. However, in a study conducted to investigate the groundwater quality of Harran Plain, which is within the provincial borders of Sanliurfa, non-compliance in terms of nitrate parameter was determined in wells in rural areas (7). According to these results; the measured parameter values are lower than the limit values, which means that these waters are suitable for use and especially drinking water.

However, in Balikligol Basin close to the study area, limit values were not exceeded in similar parameters $(5,11)$. But, in the studies carried out in Ceylanpinar Plain and Suruc Plain, it is seen that the limit values are exceeded in similar parameters (nitrate, electrical conductivity etc.) $(8,9,12,13)$. In addition, in a study conducted to investigate the groundwater quality of Harran Plain, which is within the provincial borders of Sanliurfa, non-compliance in terms of nitrate parameter was determined in wells in rural areas (14).

Considering the microbiological parameter values, the situation worsens in the summer and fall periods. The fact that drinking-usage water does not comply with the microbiological norms is an indication that the digestion residues of warm- 
blooded creatures are mixed with these waters. Therefore, drinking these waters and using them in food preparation lead to acute intestinal infections.

In 2016, in the study conducted on the increase in patient admissions with nausea, vomiting, abdominal pain and diarrhea in Elbistan District of Kahramanmaraș province, it was reported that norovirus was detected in their patients' faeces and drinking-usage water there (15).

In another study; physical, chemical and microbiological analyzes were carried out on water samples taken from public fountains located in Trabzon city centers. According to these analyzes, the physical and chemical parameters in the samples were found to be suitable except for the $\mathrm{pH}$ parameter (11\% of the $\mathrm{pH}$ parameter is not suitable). Similarly, it has been determined that these waters do not comply with the microbiological norms (16).

Siverek rural districts have a total population of 258.265 people in 2018 (146.131 people as a Center population) and have $4.314 \mathrm{~km}^{2}$ surface area, it is larger than many provincial towns in Turkey (17). The district's eastern and southern sectors display planned settlement patterns, while the northern and western regions are being rapidly settled with unplanned, irregular developments. To meet the water need of the growing population, water wells connected directly to the network were opened between the neighborhoods. Although chlorination equipment was installed in the wells, disinfection could not be done regularly and continuously. Especially in the summer and fall seasons, incompatibility was detected in terms of microbiological parameters measured at high values. The reason for this may be the chlorination that failing during these periods. It is also thought that wastewater leaks underground due to malfunctions in the existing sewage system and various factors, triggering microbiological pollution. Among the reasons that increase the risk of pollution, water cuts due to frequent interruptions or faults caused by the old water network in the district are considered. Due to these reasons, incompliance was detected in terms of coliform bacteria in 15 water samples, $E$. coli in nine water samples and enterococci values in three water samples.

Microbiological contamination presents a serious risk to public health. Called water-borne diseases; contagious diseases such as cholera, typhoid fever, polio and hairworm occur as a result of drinking feces and urine mixed water or eating foods washed or prepared with these waters. This situation has always created serious problems in societies where adequate water disinfection is not provided. Because these kinds of water-borne diseases have caused sudden and very common epidemics that can result in death in society (1). As a matter of fact, according to the results of a study conducted in Switzerland, it was reported that individuals who do not use chlorinated water after any problems due to any reason in the water distribution system have more symptoms of vomiting and acute intestinal infection than those who use chlorinated water (18).

For this reason, in both the short and long term, leaks from the drainage system near wells opened within neighborhoods should be identified and the necessary preventative measures are taken, and a $50 \mathrm{~cm}$ high 1-2 meter in diameter concrete barrier, the mixing of surface waters into the wells should be prevented. Further to this, chlorination should be carried out consistently and continuously, and to ensure an adequate supply of water, the wells should all be connected to the nearest reservoir and from there connected to the network.

In the long term, Siverek, one of Turkey's largest districts, needs to achieve the goal of the sufficiency of quality and supply of water sources. The existing network, systems and reservoirs need to be updated. The most suitable water source, The Ataturk Dam Reservoir is $30 \mathrm{~km}$ from the center of Siverek. An appropriate purification system combined with a sufficient number of intermediate reservoirs would 
provide the district with enough quality drinkingusage water for many years to come.

As a result; with the get started to activation of GAP, Sanliurfa and its districts received significant migration. This also increased rural to central migration. In addition, after the civil war in Syria, it has been the city most affected by the refugees who came to our country. This population pressure also had significant negative impacts on water management in terms of environment, health and infrastructure.

\section{ACKNOWLEDGMENTS}

This study received financial support from Harran University BAP Unit (Project No. 17198).

\section{KAYNAKLAR}

1. Çağatay G. Çevre Sağlığı (Çevre ve Ekoloji Bağlantılarıyla). Ankara: Yazıt Yayıncılık. 2012.

2. İnsani Tüketim Amaçlı Sular Hakkında Yönetmelik; h t t p: / / www. mevzuat.gov.tr/Metin. Aspx?MevzuatKod=7.5.7510\&Mevzua tlliski=0), (Erişim Tarihi: 10.10.2019).

3. Siverek Kaymakamlığı. http://www.siverek. gov.tr/siverekcografi-Yapisi, (ErişimTarihi: 10.10.2019).

4. 1593 Sayılı Umumi Hıfzısshha Kanunu. https:// www. mevzuat.gov.tr/MevzuatMetin/1.3.1593. pdf), (Erișim Tarihi: 10.10.2019.).

5. Yetiș R, Atasoy AD, Demir Yetiș A, Yesilnacar MI. Hydrogeochemical characteristics and quality assessment of groundwater in Balikligol Basin, Sanliurfa, Turkey. Environ Earth Sci, 2013;78: 3310.
6. Vincy $M V$, Brilliant $R$, Pradeepkumar AP. Hydrochemical characterization and quality assessment of groundwater for drinking and irrigation purposes: a case study of Meenachil River Western Ghats, Kerala, India. Environ Monit Assess, 2015; 187: 4217.

7. Derin P, Demir Yetiș A, Yeșilnacar MI, Yapıcıoğlu P. GAP'ın en büyük sulama sahasında jeotermal sulardan kaynaklanan potansiyel ağır metal kirliliğinin araștırılması. Turk Jeol Bült, 2020; 63: 125-36.

8. Yeșilnacar MI, Demir Yetiș A, Dülgergil CT, Kumral M, Atasoy AD, Rastgeldi Doğan T, et al. Geomedical assessment of an area having high fluoride groundwater in southeastern Turkey. Environ Earth Scis, 2016; 75: 162. 
9. Selek Z, Yetis AD. Assessment of nitrate contamination in a transnational groundwater basin: a case study in the Ceylanpinar Plain, Turkey. Environ Earth Sci, 2017; 76, 698.

10. Kahraman N, Karabulut YB, Atasoy AD, Yeșilnacar MI. Harran ovası serbest akiferinde yaz ve kıș dönemleri nitrat kirliliğinin araștırılması (20142015); HU J Eng, 2016; 02: 01-8.

11. Yetis R, Atasoy AD, Demir Yetis A, Yesilnacar MI. Balıklıgöl havzası su kaynaklarının nitrat ve nitrit seviyelerinin belirlenmesi. Çukurova Üni Müh Mimar Fak Derg, 2018; 33(1): 47-54.

12. Demir Yetiș A, Yeșilnacar MI, Selek Z. Sınır așan bir Yeraltı suyu havzasında su kalitesinin belirlenmesi Ceylanpınar ovası örneği. Çukurova Üni Fen Bil Derg, 2015; 32.

13. Demir Yetiș A, Yeșilnacar MI, Selek Z. Ceylanpınar Ovası'nda yeraltı suyu tuzluluğunun coğrafi bilgi sistemi destekli incelenmesi. İklim Değ Çevre, 2018; 3(1): 51-9.

14. Yesilnacar MI, Gulluoglu MS. The effects of the largest irrigation of GAP project on groundwater quality, Sanlıurfa- Harran Plain, Turkey - Fresenius Environ Bull, 2007; 16(2): 206-11.
15. Şahan S, Yılmaz S, Topal S, Özarslan F, ÇelikerYenice A, Cemil-Göktaș D, et al. Kahramanmaraș ili Elbistan ilçesinde görülen akut barsak enfeksiyonu vaka artıșı incelemesi, Ağustos 2016. Turk Hij Den Biyol Derg, 2017; 74 (EK-1): 13-20.

16. Cankayalı S, Topbaș M, Yavuzyılmaz A, Yeșilbaș Üçüncü Ş, Karakullukçu S, Kolaylı CC, et al. Trabzon halk çeșmelerinin fiziksel, kimyasal, mikrobiyolojik yönden değerlendirilmesi, Turk Hij Den Biyol Derg, 2017; 74(EK-1): 21-8.

17. Temel istatistik bilgiler nüfus ve demografi. http:// www. tuik.gov. tr/UstMenu.do?metod=temelist); 2018, (Erișim Tarihi:10.10.2019).

18. Söderbergh MS, Bylund J, Malm A, Simonsson, M. Gastrointestinal illness linked to incidents in drinking water distribution networks in Sweden. Water Res, 2017; 122: 503-11. 